\title{
POPULATIONAL GENETIC STRUCTURE OF FREE-LIVING MANED WOLVES (Chrysocyon brachyurus) DETERMINED BY PROTEIC MARKERS
}

\author{
DE MATTOS, P. S. R., ${ }^{1}$ DEL LAMA, M. A., ${ }^{2}$ TOPPA, R. H. ${ }^{3}$ \\ and ARNO RUDI SCHWANTES, A. R. ${ }^{2}$ \\ ${ }^{1}$ Médico veterinário, consultor do plano de manejo do lobo-guará \\ ${ }^{2}$ Departamento de Genética e Evolução, Universidade Federal de São Carlos \\ ${ }^{3}$ Biólogo \\ Correspondence to: Paulo Sergio Ribeiro de Mattos, Rua João Batista Arruda, 227, CEP 13566-120, \\ São Carlos, SP, Brazil, e-mail: pmattos@iris.ufscar.br \\ Received April 9, 2003 - Accepted June 23, 2003 - Distributed August 31, 2004
}

(With 1 figure)

\begin{abstract}
Electrophoretic analysis of presumptive twenty gene loci products was conducted in hemolisates and plasma samples of twenty-eight maned wolves (Chrysocyon brachyurus) from an area in northeastern São Paulo State, Brazil. The area sampled was divided into three sub-areas, with the Mogi-Guaçu and Pardo rivers regarded as barriers to the gene flow. The polymorphism degree and heterozygosity level (intralocus and average) estimated in this study were similar to those detected by other authors for maned wolves and other species of wild free-living canids. The samples of each sub-area and the total sample exhibited genotype frequencies consistent with the genetic equilibrium model. The values of the F-statistics evidenced absence of inbreeding and population subdivision and, consequently, low genetic distances were found among the samples of each area.
\end{abstract}

Key words: maned wolf, population genetics, conservation, genetic markers.

\section{RESUMO}

\section{Estrutura genética populacional de lobos-guarás (Chrysocyon brachyurus) de vida livre determinada por marcadores protéicos}

Os produtos protéicos de 20 locos gênicos foram analisados eletroforeticamente em hemolisados e plasma de 28 lobos-guarás (Chrysocyon brachyurus) de uma área da região Nordeste do Estado de São Paulo, Brasil. A área de estudo foi dividida em 3 subáreas, considerando os rios Mogi-Guaçu e Pardo como barreiras ao fluxo gênico. O grau de polimorfismo e o nível de heterozigosidade (intraloco e média) estimados neste estudo foram semelhantes aos observados por outros autores para lobosguarás e outras espécies de canídeos de vida livre. As diferentes amostras e a amostra total demonstraram freqüências genotípicas nos locos polimórficos consistentes com o modelo de equilíbrio genético. Os valores da estatística-F evidenciaram ausência de endocruzamento e de estruturação populacional e, como conseqüência, foram encontrados baixos valores de distância genética entre as amostras correspondentes a cada subárea.

Palavras-chave: lobo-guará, Chrysocyon brachyurus, conservação, genética de populações, marcadores genéticos. 


\section{INTRODUCTION}

The maned wolf (Chrysocyon brachyurus) is a characteristic canid of cerrado bioma and its occurrence area includes Central Brazil, Paraguay, and small areas of Argentina, Bolivia, and Peru (Dietz, 1984). Due to its position at the top of the alimentary chain, the maned wolf presents ecological functions indispensable to ecosystem stability, e.g., seed dispersion. Although the conservation of this species is fundamental, mainly to the equilibrium of cerrado bioma, this species has been included since 1970 in the official list of animals in extinction (Coimbra-Filho, 1972).

Key to understanding this threat is knowing that the principal economic activity in northeastern São Paulo State is agriculture, together with processing industries based on sugarcane, citrus, and eucalyptus cultivation. Other land uses include pasturing, and cultivating coffee, corn, soy, and peanuts. A landscape description of the municipality of Luiz Antônio made by Pires et al. (1995) can be considered virtually prototypical of the whole area. In this region, the custom of burning sugarcane before harvest causes many animal deaths and provokes fires in native vegetation areas (Pires et al., 2000). Deaths of maned wolves through burning, use of firearms, or being run over, have been registered. Moreira et al. (1998) considered deleterious human influence in the habitat of maned wolves to be more intense in the southeast than in the midwestern Brazilian states. This may be happening because of the greater fragmentation degree and habitat reduction caused by intense agricultural exploitation and the urbanization of southeastern Brazil.

For species in extinction, estimations of inbreeding levels and populational structure can supply important data in planning conservation handling of these species. As a result of these studies, a larger frequency of matings between related animals has come to be expected in populations with small numbers of individuals located in areas that hinder gene flow among populations. Such inbreeding can lead to an increase in the occurrence of deleterious characteristics in a population, e.g., decrease in fertility and immunological resistance in individuals (Woodroffe \& Ginsberg, 1998). Genetic studies of populational structure can contribute to the evaluation of geographical accidents and human activity impacts that may be affecting migration patterns and reproduction of given species. Thus, electrophoretic analysis of proteic markers has been a useful tool in studyng the populational genetics of maned wolves and other wild canids (Ferrel et al., 1980; Kennedy et al., 1991; Moreira et al., 1998). The present work was intended to verify the inbreeding level and populational structure in free-living maned wolves in northeastern São Paulo State, Brazil, by evaluating the extent to which the Mogi-Guaçu and Pardo rivers may be blocking the gene flow of the species.

\section{MATERIAL AND METHODS}

This study was carried in a $19,224 \mathrm{~km}^{2}$ area in northeastern São Paulo State (Fig. 1). Considering the Mogi-Guaçu and Pardo rivers as limiting factors of the gene flow, 3 sub-areas were proposed: subarea 1, between the Mogi-Guaçu and Pardo rivers; sub-area 2, south of the Mogi-Guaçu River; and subarea 3, north of the Pardo River. All occurrences cited in this work were georeferenced by the Global Positioning System and plotted on a digital thematic map by MapInfo Program version 4.1 (Table 1). In this area twenty-eight maned wolves were caught and identified by tattoo; there were 7 animals in area 1,13 in area 2 , and 8 in area 3. Blood samples were collected from captured animals, which were then freed after recovery from the anesthetic. The samples were collected in heparinized tubes and maintained under refrigeration, within a temperature range of $2-8^{\circ} \mathrm{C}$, during transport to the laboratory.

In the laboratory, the samples were centrifuged to obtain plasma. The precipitate (erythrocytes) was washed three-fold in sodium chloride solution at $0.9 \%$ before freezing (at $-20^{\circ} \mathrm{C}$ ). The samples were then submitted to electrophoresis and specific staining (Harris \& Hopkinson, 1978) for analysis of the following proteic systems: phosphohexose isomerase (Gpi), peptidase B (Pep-B), lactate dehydrogenase $(L d h)$, phosphogluconate dehydrogenase $(P g d)$, hemoglobin $(H b)$, haptoglobin $(H p)$, malate dehydrogenase $(M d h)$, superoxide dismutase $(S o d)$, albumin, general proteins ( $G p-1, G p-2, G p-3$, and $G p-4)$, acid phosphatase $(A c p)$, carbonic anidrase II (CA II), and glioxalase $(G l o)$. The gels, buffers, and electrophoretic run conditions used are described in Table 1 .

For polymorphic loci, occurrence of HardyWeinberg equilibrium was investigated for the three sub-area samples as well as the total sample. Wright's analysis (1965) of the standardized variance of allele frequencies was done to verify population sub- 
division and inbreeding. Estimates of the genetic distances were carried out through Nei's method (1978) corrected for small samples. These estimates were obtained with Biosys-1 software (Swofford \& Selander, 1981).

\section{RESULTS}

Among the proteic markers representing twenty presumptive gene loci studied, only the Gpi, Pep$B, G l o$, and $G p-4$ loci exhibited enzyme variation. Allele frequencies in these loci in each sub-area and in the total area samples are shown in Table 2. The polymorphism degree in all individuals sampled was $20 \%$ and a value close to 1.2 was found for the mean allele number per locus. Intralocus heterozygosity values such as $0.25,0.42,0.21$, and 0.25 were observed for the Gpi, Pep-B, Gp-4, and Glo loci, respectively, and the average heterozygosity was estimated as 0.057 .

The Hardy-Weinberg equilibrium tests showed no significant values, indicating that the samples were in genetic equilibrium for the analyzed loci (Table 2). Wright's F-statistics analysis (1965) evidenced a nonsignificant interpopulational differentiation coefficient $\left(\mathrm{F}_{\mathrm{st}}\right)$ (Table 3$)$, indicating the absence of barriers to gene flow among samples of the three subareas, and a nonsignificant inbreeding coefficient $\left(\mathrm{F}_{\mathrm{is}}\right)$ (Table 3), which signals no significant heterozygosity reduction as a consequence of matings between related animals. According to these results, we postulate that the Mogi-Guaçu and Pardo rivers did not constitute a barrier to gene flow of the species. As expected for a non-structured population, low genetic distance values like $0.007,0.079$, and 0.054 between sub-areas 1 and 2, 1 and 3, and 2 and 3, respectively, were found.

TABLE 1

Electrophoretic conditions used for the analysis of twenty gene products in maned wolf samples. TC, TB, EBT, and TEMM mean tris-citrate, tris-borate, tris-borate-EDTA, and tris-EDTA- maleic anhydride-magnesium chloride, respectively. The gel types used were: $A$, corn starch at $14 \%$; $B$, potato starch at $2 \%$ and agarose at $0.8 \%$; and $C$, polyacrylamide at $10 \%$.

\begin{tabular}{|l|c|c|c|c|c|c|}
\hline \multicolumn{1}{|c|}{ Loci } & V & A & Time & Electrode buffer & Gel buffer & Gel type \\
\hline$A c p, M d h$ & 220 & 50 & $5 \mathrm{~h}$ & TC 8.0 & TC 8.0 & $\mathrm{~A}$ \\
\hline Pep-B, $C A I I, H p$ & 160 & 30 & $5 \mathrm{~h}$ & Borate 8.3 & TC 8.0 & $\mathrm{~A}$ \\
\hline$P g i$, Sod, Est-D, $P g d, L d h$ & 150 & 50 & $5 \mathrm{~h}$ & TC 6.6 & Histidine 6.0 & $\mathrm{~A}$ \\
\hline$H b$ & 400 & Free & $45 \mathrm{~min}$ & EBT 8.9 & EBT 8.9 & $\mathrm{~A}$ \\
\hline Glo & 80 & 40 & $4 \mathrm{~h}$ & TEMM 7.4 & TEMM 7.4 & $\mathrm{~B}$ \\
\hline Alb, $G p 1-4$ & 2500 & 70 & $2 \mathrm{~h}$ & TB 8.0 & TC 8.7 & $\mathrm{C}$ \\
\hline
\end{tabular}

TABLE 2

Allele frequencies and $\chi^{2}$ values for Hardy-Weinberg equilibrium in three samples of maned wolves (Chrysocyon brachyurus) from an area in northeastern São Paulo State.

\begin{tabular}{|c|c|c|c|c|c|c|}
\hline \multirow{2}{*}{ Loci } & \multirow{2}{*}{ Alleles } & \multicolumn{4}{|c|}{ Allele frequencies } & \multirow{2}{*}{$\chi_{\text {HW }}^{2}$} \\
\hline & & Area 1 & Area 2 & Area 3 & Total area & \\
\hline \multirow[t]{2}{*}{$P g i$} & $S$ & 0.857 & 0.770 & 0.562 & 0.732 & \multirow{2}{*}{$\begin{array}{c}3.681(1 \mathrm{FD}) \\
\mathrm{NS}\end{array}$} \\
\hline & $F$ & 0.230 & 0.230 & 0.438 & 0.268 & \\
\hline \multirow[t]{2}{*}{ Рep-B } & $S$ & 0.917 & 0.875 & 0.562 & 0.788 & \multirow{2}{*}{$\begin{array}{c}1.871(1 \mathrm{FD}) \\
\mathrm{NS}\end{array}$} \\
\hline & $F$ & 0.083 & 0.125 & 0.438 & 0.212 & \\
\hline \multirow[t]{2}{*}{$G p-4$} & $S$ & 0.786 & 0.923 & 0.812 & 0.857 & \multirow{2}{*}{$\begin{array}{c}0.437 \text { (1 FD) } \\
\mathrm{NS}\end{array}$} \\
\hline & $F$ & 0.214 & 0.077 & 0.188 & 0.142 & \\
\hline \multirow[t]{2}{*}{ Glo } & $F$ & 0.857 & 0.846 & 0.937 & 0.875 & \multirow{2}{*}{$\begin{array}{c}0.571(1 \mathrm{FD}) \\
\mathrm{NS}\end{array}$} \\
\hline & $S$ & 0.143 & 0.154 & 0.063 & 0.125 & \\
\hline
\end{tabular}




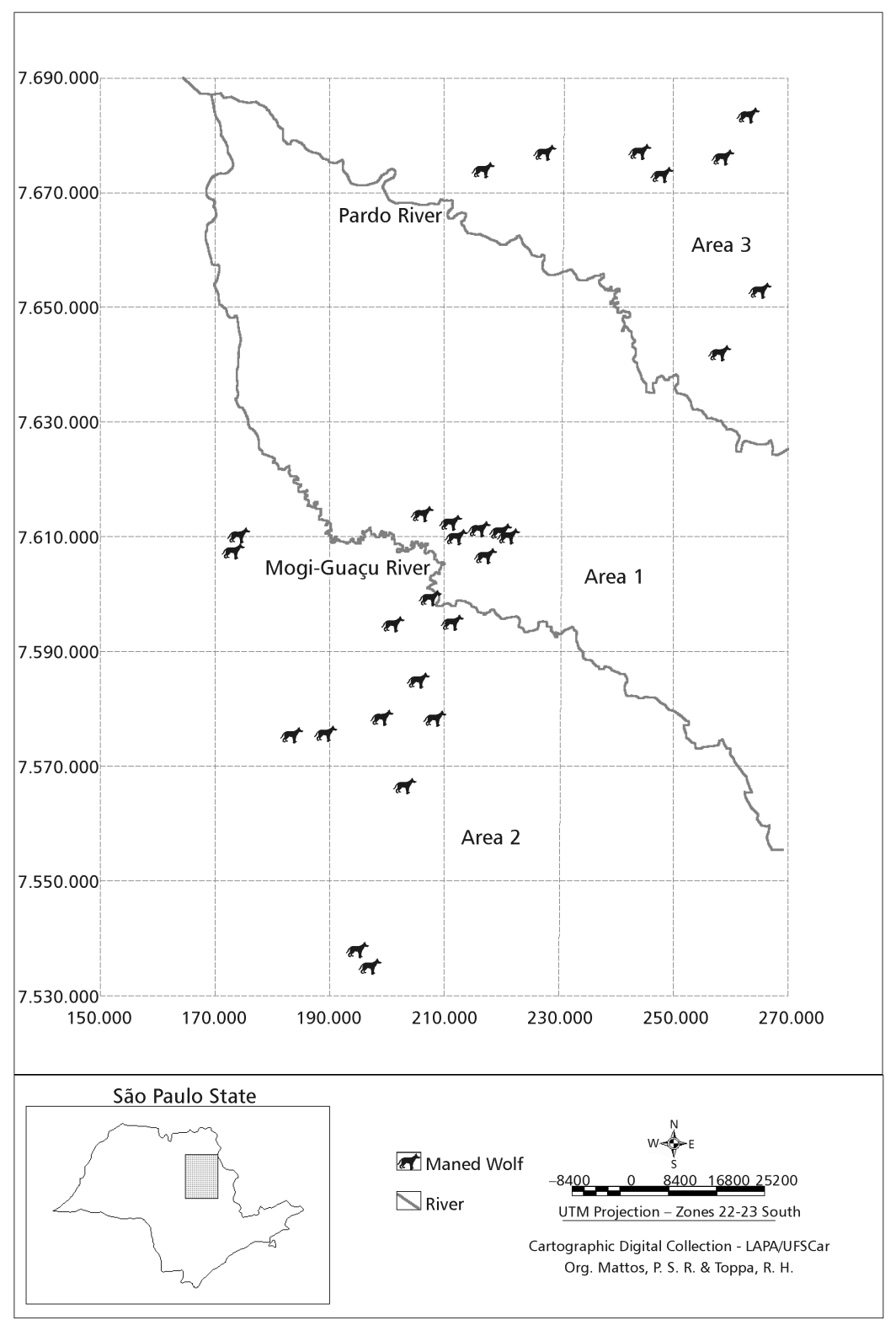

Fig. 1 - Thematic map of space distribution in places of capture of maned wolves (Chrysocyon brachyurus), in northeastern São Paulo State.

TABLE 3

F-Statistic coefficients $\left(F_{I S}, F_{S T}\right.$, and $\left.F_{I T}\right)$ and their significance considering as a single population the three maned wolf (Chrysocyon brachyurus) samples collected in a northeastern area of São Paulo State.

\begin{tabular}{|l|c|c|c|c|c|c|}
\hline \multicolumn{1}{|c|}{ Loci } & $\mathbf{F}_{\text {ST }}$ & $\boldsymbol{\chi}^{\mathbf{2}}$ & $\mathbf{F}_{\text {IS }}$ & $\boldsymbol{\chi}^{\mathbf{2}}$ & FD & F $_{\text {IT }}$ \\
\hline Pgi & 0.077 & 4.312 & 0.342 & 3.275 & 2 & 0.393 \\
\hline Pep- $B$ & 0.148 & 7.696 & -0.495 & 6.371 & 2 & -0.274 \\
\hline$G p-4$ & 0.026 & 1.456 & 0.143 & 0.573 & 2 & 0.165 \\
\hline Glo & 0.016 & 0.896 & -0.154 & 0.664 & 2 & -0.136 \\
\hline Mean & 0.075 & 14.360 & -0.011 & 10.883 & 8 & 0.064 \\
\hline
\end{tabular}




\section{DISCUSSION}

The polymorphism degree verified for the collected samples in the whole area $(20 \%)$ was similar to that described by other authors for the maned wolves and for other phylogenetically related canids. Moreira et al. (1998) detected in samples of maned wolves a polymorphism degree of $21.4 \%$ in a low anthropic pressure area (Brasília and Goiânia) and $14.3 \%$ in a high anthropic pressure area (São Paulo and Minas Gerais). The parameter used to evaluate anthropic pressure was based on human populational density. Even so, this anthropic pressure estimator must be regarded with caution, since areas with low populational density can present high fragmentation and habitat reduction, mainly because of agricultural activity. Other genetic variability measures by protein markers have been reported by Kennedy et al. (1991) and Waine et al. (1991) in gray wolves (Canis lupus). Kennedy et al. (1991) detected $13.5 \%$ of polymorphic loci in wild gray wolves, a smaller value than that verified in the present work. Waine et al. (1991), in analyzing the genetic variability of wild gray wolves in a continental area of North America, estimated at $20 \%$ the polymorphic loci degree. These authors compared their data with those for an isolated wild gray wolf population of an insular area (Isle Royale) and verified a much lower polymorphism level (8\%) than that of the continental population.

The average heterozygosity value in the present work $(5.7 \%)$ was similar to values estimated by Moreira et al. (1998) (1.4\% to 8.3\%) for maned wolf populations studied.

The nonsignificant interpopulational differentiation coefficients $\left(\mathrm{F}_{\mathrm{ST}}\right)$ verified in this work (see Table 3) indicate absence of barriers to gene flow among the samples of the three sub-areas. These results suggest that the wolves not only have been crossing the rivers but may be continuing to do so. The Hardy-Weinberg equilibrium in the total sampling (Table 2) reinforces this conclusion. As expected for a non-subdivided population, the genetic distance values among the samples of the three areas were low (from 0.054 to 0.079 ).

Stockwell et al. (1996) discusses the validity of animal translocations to increase allelic diversity. This strategy has been proposed as a conservation measure in genetically depauperated populations. However, the estimated parameters shown in the present work indicated no heterozygosity reduction in the analyzed samples. Absence of genetic variation reduction and no inbreeding occurrence indicate that translocations are not necessary in the studied area. These findings acquire greater relevance if we consider the possibly deleterious effects to a species of translocation, e.g., introduction of infectious diseases into a given population (Cunningham, 1996; McCallum \& Dobson, 1995) and incapacity of the animals to adapt to the places into which they were introduced (Campbell, 1980).

Acknowledgements - Thanks are due to Maria Luiza Schwantes, Maria Isabel de Godóy, Elisabete Pereira Barreto, and Sílvia Helena Machado for their help in the electrophoretic analyses, and to José E. Mantovani, Keiko K. Mattos, José S. R. Pires, José E. Santos, and Carlos H. Oliveira for their help in field work. We also thank the Fundação de Amparo à Pesquisa do Estado de São Paulo (FAPESP) for financing the research and granting scholarships to Paulo S. R. Mattos, and the Conselho Nacional de Pesquisas $(\mathrm{CNPq})$ for financial support of this research.

\section{REFERENCES}

CAMPBELL, S., 1980, Is reintroduction a realistic goal? In: M. E. Solé \& B. W. Wilcox (eds.), Conservation biology: an evolutionary-ecological perspective. Sinauer Association, Sunderland (MA), 395p.

COIMBRA-FILHO, A. F., 1972, Mamíferos ameaçados de extinção no Brasil. Academia Brasileira de Ciências, Rio de Janeiro, 268p.

CUNNINGHAM, A. A., 1996, Disease risks of wildlife translocations. Conserv. Biol., 10: 349-353.

DIETZ, J. M., 1984, Ecology and social organization of the maned wolf (Chrysocyon brachyurus). Smith. Contr. Ecol., 392: 1-24.

FERREL, R. E., MORIZOT, D. C., HORN, J. \& CARLEY, C. J., 1980, Biochemical markers in a species endangered by introgression: the red wolf. Biochem. Genet., 18: 39-49.

HARRIS, H. \& HOPKINSON, D. A., 1978, Handbook of enzyme electrophoresis in human genetics. North Holland Publ. Co., Amsterdam, 670p.

KENNEDY, P. K., KENNEDY, M. L., CLARKSON, P. L. \& LIEPINS, I. S., 1991, Genetic variability in natural populations of the gray wolf, Canis lupus. Can. J. Zool., 69: 1183-1188.

McCALLUM, H. \& DOBSON, A., 1995, Detecting disease and parasite threats to endangered species and ecosystems. Tree, 10: 190-194.

MOREIRA, J. R., GUIMARÃES, N. K., PILLA, E. J. S., CONTEL, E. P. B. \& BEM, A. R. D., 1998, Estudo preliminar da variabilidade genética do lobo-guará (Chrysocyon brachyurus). EMBRAPA (Comunicado Técnico), 30: 1-10.

NEI, M., 1978, Estimation of average heterozygosity and genetic distance from a small number of individuals. Genetics, 89 : 583-590. 
PIRES, J. S. R., SANTOS, J. E., PIRES, A. M. Z. C., MANTOVANI, J. E. \& PAESE, A. 2000, Estratégias "inter situ" de conservação: elaboração de cenários regionais para a conservação da biodiversidade. Anais do V Simpósio de Ecossistemas Brasileiros: Conservação. Vitória, Espírito Santo, $10-15$ out. 2000.

PIRES, J. S. R. 1995. Análise ambiental voltada ao planejamento $e$ gerenciamento do ambiente rural: abordagem metodológica aplicada ao município de Luiz Antônio, SP. Tese de Doutorado em Ecologia, Programa de Pós-graduação em Ecologia e Recursos Naturais, Universidade Federal de São Carlos, São Carlos,

STOCKWELL, C. A., MULVEY, M. \& VINYARD, G. L., 1996, Translocations and preservation of allelic diversity. Conserv. Biol., 10: 1133-1141.
SWOFFORD, D. L. \& SELANDER, R. B., 1981, Byosys-1: a Fortran program for the comprehensive analysis of electrophoretic data in population genetics and systematics. J. Hered., 72: 281-283.

WAYNE, R. K., GILBERT, D. A., LEHMAN, N., HANSEN, K., EISENHAWER, A., GIRMAN, D., PETERSON, R. O., MECH, L. D., GOGAN, P. J. P., SEAL, U. S. \& KRUMENAKER, R. J., 1991, Conservation genetics of endangered Isle Royale gray wolf. Conserv. Biol., 5: 41-51.

WOODROFFE, R. \& GINSBERG, J. R., 1988, Edge effects and the extinction of populations inside protected areas. Sci., 280: 2126-2128.

WRIGHT, S., 1965, The interpretation of population structure by F-statistics with special regard to systems of mating. Evolut., 19: 395-420. 